\title{
U.S. ARMS CONTROL POLICY: CONGRESSIONAL CONSTRAINT OR MIC BUSINESS AS USUAL?
}

\author{
Michael O'Keefe \\ University of Kansas
}

Mid-American Review of Sociology 1978, Vol. 3, No. 1:63-82

This paper entertains the possibility that a military-industrial complex does in fact exist; that it is not constrained by Congress; that arms policy continues to serve this complex; and that in fact, Congress legitimates MIC activity through ritualistic conflict. Laurance's hypothesis that Congress has recently taken a more active role in the policy process is challenged. Using Yarmolinsky's broader conception of arms policy, it is argued that arms policy has not significantly changed even though Congressional action has become more conflictual. Finally, it is argued that the changed Congressional role is best understood in terms of Edelman's reversal of systems theory.

During the past fifteen years, critics of U.S. arms policy have pointed to a "military-industrial complex" (MIC) as being at the root of that policy. The ultimate power in making arms policy has been limited to influence from the following: corporate elites (Horwitz, 1970; Williams, 1970; Perlo, 1963; and Kolko, 1970); the military establishment (Barnet, 1969; Lens, 1970; Heilbroner, 1970); or, managerial elites (Melman, 1970, 1974; Barnet, 1971). Motivation has included profit, expansion of bureaucratic control and power. Whatever the particular configuration, the underlying current has been that U.S. arms policy has been ultimately made by non-elected officials in pursuit of their self-interest, and the result has been expanded arms production.

These theorists have not been without critics, however. One of the more telling arguments has focused upon the Congressional role in the appropriations process. With ultimate control over 
expenditures for arms production, the Congress is theoretically a constraining force upon a military industrial complex. Spanier and Ulsamer (1974) argue in support of Cohen's (1973) hypothesis that economic interest groups have an impact upon defense policy, but only within the constraints set by pre-established political policies based upon national security needs. Russet (1969) was unable to discover empirical relationships between Congressional roll call voting on defense issues and defense contractor influence. Kantor (1972:142) argues most strongly that:

The widely-held notion that an uncritical Congress passively grants whatever appropriations are requested by the President and the Pentagon does not do justice to the reality of the pattern of the Congressional changes in the defense budget, nor does it illuminate the past and potential Congressional role in influencing the content of foreign policy.

A more recent critic (Laurance, 1976) has attempted to empirically demonstrate that in recent years, the Congress has increased its constraining role upon the defense bureaucracy. Since the Congressional "rubber stamp" role is vital to the arguments of MIC theorists, it appears that Laurance's findings seriously challenge the MIC thesis.

The purpose of this paper is to entertain the possibility that a military-industrial complex as conceptualized by Melman (1974) does in fact exist; that it is not constrained by Congress; that arms policy continues to serve this complex; and that in fact, Congress legitimizes MIC activity through ritualistic conflict. Laurance's (1976) hypothesis that the Congress has taken a more active role in the policy process since 1969 will be analyzed to demonstrate that it rests upon a narrow conception of arms policy. Using a broader conception of arms policy developed by Yarmolinsky (1972), it will be demonstrated that arms policy has not significantly changed even though Congressional action has become more conflictual. Finally, it will be argued that the changed Congressional role is best understood in terms of Edelman's (1974) reversal of systems theory.

\section{PERMANENT WAR ECONOMY}

Lieberson (1972:56) has argued that the existence of a military-industrial complex is beyond question:

There is little reason to doubt that a "military-industrial complex" exists if by this phrase is meant a set of commonly shared interests between the military and some major corporations. Certain striking features .... are: The interchange of personnel between the military and their corporate suppliers, the network that exists within the business sector, and the role of large corporations as suppliers to the military.

The "complex" is generally considered to include the administrative decisionmakers within the defense bureaucracy whose primary concern is defense policy, and that portion of the industrial sector for whom arms manufacture is an important portion of their enterprise. The dominant force in this complex however, is the defense bureaucracy. Yarmolinsky (1972) observed that the ability of a contractor to obtain a defense budget "add-on" was dependent upon Pentagon approval. It is the power of the defense bureaucracy and its attendent consequences for the economy that is the focus of Melman's $(1974,1976)$
work. $^{2}$

Melman's thesis is that bureaucratic power, located within the defense establishment, is achieving increasing control over large parts of the economic and political institutions in the United States through its monopoly on contracting and information. The result is a permanent war economy managed by this bureaucracy, not to be confused with a "mixed economy" (1974:22):

The war economy of the United States is no mere extension of private capitalism. Neither is it an undifferentiated state capitalist economy... state capitalism has been given the particular form of a war economy. With a duration extending for thirty years, and solid plans for more to come it is no editorial excess to understand it as a permanent war economy. 
Not only has defense manufacture penetrated the economic structure itself, but the methods of contracting have changed traditional concepts of incentives, inventiveness, risk, and profit which in turn are creating a stagnant economic growth structure. The industrial segment is served best by receipt of contract awards with a higher profit-to-risk ratio than is possible in non-defense sectors of industry (Perlo, 1963; Magdoff, 1969; Kaufman, 1970; Stevenson, 1973). Stevenson has demonstrated that for the 1961-1969 period, arms contracting is at least as lucrative as other enterprises in the industrial sector, as is indicated in Table 1. With the promise of risk-free or low-risk profit for industry and threats of dire consequences resulting from decreased arms manufacture for the economy, the defense bureaucracy has been able to amass unrivaled power.

Melman's notion of bureaucratic power is consistent with those of other organization theorists (Downs, 1966; Thompson, 1967; Wamsley and Zald, 1973) who argue that a viable organization seeks to stablize its environment (Thompson) or external political economy (Wamsley and Zald). The successful organization appears to be the one that makes itself the center of dependency relationships. Melman argues that the defense bureaucracy has accomplished just that.

Critical to Melman's thesis is a "rubber-stamp" Congress supportive of executive branch arms policy, for ultimately, the policies of the defense bureaucracy are formally subject to Congressional review. Wamsley ${ }^{3}$ captured a great deal of the literature supportive of the "rubber stamp" notion with his conceptualization of an "iron triangle" of bureaucratic agencies, Congressional committees, and special interests that function to make public policy. However, as noted above, there is also a great deal of literature which asserts that the Congress is in fact a constraining force.

\section{CONGRESSIONAL CONSTRAINT}

Laurance (1976) divides Congressional activity on defense policy into two periods. During the 1947-1967 period, the
TABLE 1

Average profit rate of defense industries by

year (1961-1969) compared with other industries

\begin{tabular}{lcccccccccc}
\hline & 1969 & 1968 & 1967 & 1966 & 1965 & 1964 & 1963 & 1962 & 1961 \\
$\begin{array}{l}\text { Top 24 Military } \\
\text { Contractors }\end{array}$ & 9.9 & 13.1 & 13.7 & 14.9 & 14.8 & 13.6 & 13.0 & 13.7 & 10.3 \\
$\begin{array}{c}\text { Top 50\% of all } \\
\text { Military } \\
\text { Contractors }\end{array}$ & 9.8 & 13.0 & 13.4 & 14.9 & 14.7 & 13.5 & 12.8 & 13.4 & 10.2 \\
$\begin{array}{c}7 \text { Military-Industrial } \\
\text { Complex Giants* }\end{array}$ & 7.7 & 12.9 & 11.9 & 17.8 & 18.6 & 15.5 & 16.0 & 16.7 & 10.9 \\
$\begin{array}{c}\text { Top 500 Industrial } \\
\text { Corporations }\end{array}$ & 11.3 & 11.7 & 11.3 & 12.7 & 11.8 & 10.5 & 9.9 & 8.9 & 8.3 \\
$\begin{array}{c}\text { SOURCE: Paul Stevenson, "The Military-Industrial Complex: An Examination of the } \\
\text { Nature of Corporate Capitalism in America," Journal of Political and Military } \\
\text { Sociology. 1:2 (1973) p. 252. }\end{array}$ \\
$\begin{array}{c}\text { (*General Dynamics, Lockheed, United Aircraft, McDonnel Douglas, Boeing, North } \\
\text { American Rockwell, Grumman.) }\end{array}$
\end{tabular}


Congress did in fact act as a "rubber stamp":

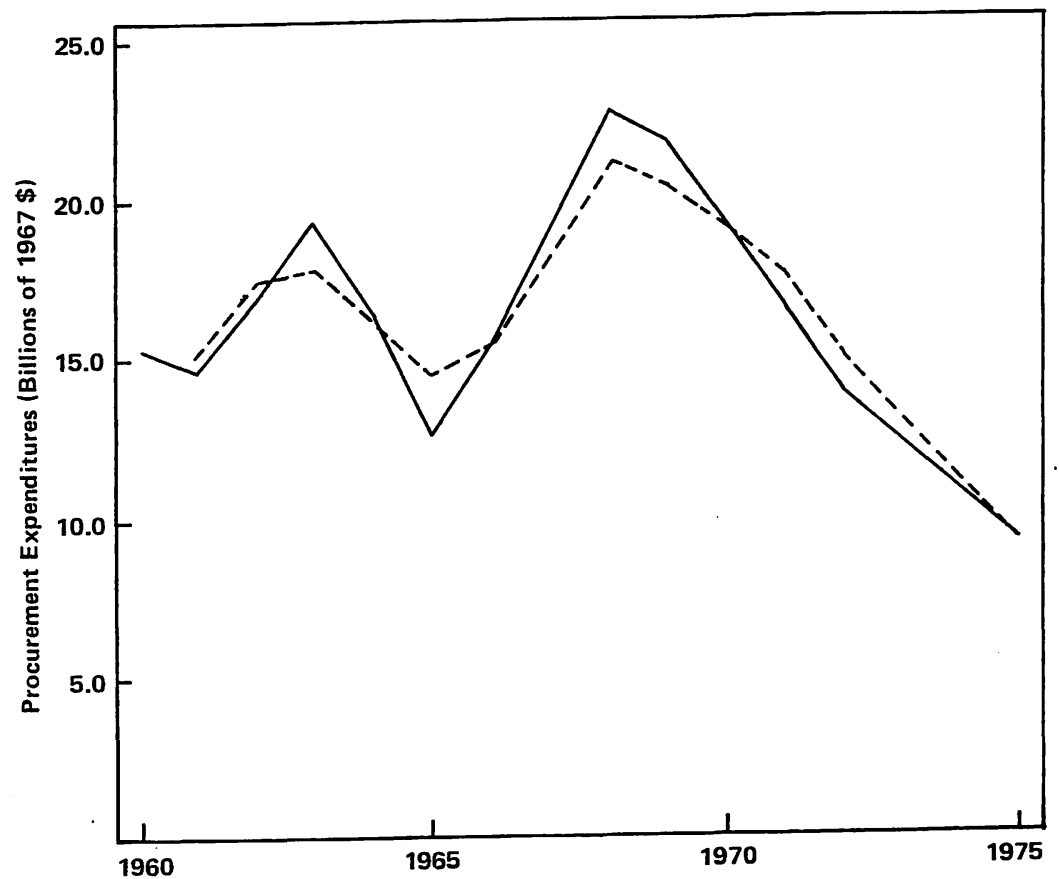

FIGURE 1: U.S. Procurement Budget Category Outlays, 1960-1975 (in billions of 1967 1ollars). Broken line indicates a three year moving average trend line. SOURCE: Statistical Abstracts.
(1) The Congress processed only "structural" (Huntington, 1961) as opposed to strategic issues;

(2) when Congress acted upon strategic issues, it was mainly concerned with domestic impact;

(3) Congress acted as a conduit for executive programs in the defense area, as compared with their actions on other policy areas; and

(4) when it acted on defense programs, it was generally to support increases in executive branch programs.

The reasons given by Laurance were the organization of Congress, executive branch monopoly of intelligence and technology information, and general public support for executive defense programs. For this period, then, Laurance's findings are supportive of Melman's thesis.

However, Laurance argues that important changes in the nature of the Congressional defense decision-making process began to occur in 1967 and 1968, such that the Congressional role during the 1968-1974 period would be significantly different. The following changes are noted:

(1) A decreased number of defense issues which functionally bypass the Congress.

(2) Conflict within the Congress and between the Congress and the executive branch over budgets.

(4) Increased alternative and mass public pressure to decrease defense spending.

(5) Significant internal dissent in the Senate Armed Forces Committee.

(6) Increased floor debate and amendments in Senate authorization legislation.

These changes resulted in policy outputs different from those of the earlier period. Figure 1 graphically presents the changed trend in outlays for the "Procurement" category of the defense budget. 
A model of Laurance's proposition that changes in Congress' external environment have produced internal change, in turn leading to different policy, can be roughly approximated using analysis of variance. If the outputs are in fact changed, then we should expect these outputs from the later period to constitute a statistically different population from those of the earlier period. Tables 2, 3, and 4 demonstrate that this is in fact the case for "Procurement," "Research, Development, Testing and Evaluation," (RDT\&E), and "Procurement plus RDTE" expenditures-the categories of the defense budget most applicable for arms policy. The time periods were lagged to allow for the translation of policy decisions into actual outlays. ${ }^{4}$

Laurance's findings appear initially to challenge the "rubber stamp" Congress hypothesis which is vital to MIC theory. This can only be the case, however, if one uses a narrow conception of arms policy. Melman's thesis is that the economy is based upon war production-not that the government funds war production. By reconceptualizing arms policy, it can be demonstrated that while Congressional activity has changed, arms policy has not.

\section{ARMS POLICY}

Following Yarmolinsky (1972), arms control policy should be differentiated from national security policy as but one of its subconcepts (see Figure 2). Foreign policy (often called national security policy) involves the "selection of national goals in the world, some of which the national may seek to achieve in whole or in part, by military means" (Yarmolinsky, 1972:280).

Arms control policy itself can be further divided into two subconcepts: 1) procedural policy which involves "the choice of military means to be available as instruments of foreign policy in the event that ,they are needed"; and, 2) substantive policy which involves "the advance determination as to which military means will be employed" (pp. 280-281, 283). Thus, procedural arms policy is concerned primarily with the deployment of military means, while substantive policy is concerned with the size and scope of the force structure, which includes weapons systems.
U.S. Arms Control Policy

TABLE 2

Analysis of variance between Laurance's time periods (lagged) and procurement expenditures (1967\$)

\begin{tabular}{|c|c|c|c|c|c|}
\hline Source & D.F. & Sum of Squares & Mean Squares & F Ratio & F Prob. \\
\hline Between Group & 1 & 64.3902 & 64.3902 & 5.669 & $>.050$ \\
\hline Within Groups & 13 & 147.6636 & 11.3587 & & \\
\hline \multirow[t]{5}{*}{ Total } & 14 & 212.0538 & & & \\
\hline & oup & Mean & \multicolumn{3}{|c|}{ Standard Deviation } \\
\hline & & 17.4047 & \multicolumn{3}{|c|}{3.2780} \\
\hline & 1975 & 13.1755 & \multicolumn{3}{|c|}{3.5129} \\
\hline & & 15.7130 & \multicolumn{3}{|c|}{3.8919} \\
\hline
\end{tabular}

TABLE 3

Analysis of variance between Laurance's two time periods (lagged) and RDTE expenditures (1967\$)

\begin{tabular}{|c|c|c|c|c|c|}
\hline Source & D.F. & Sum of Squares & Mean Squares & F Ratio & F Prob. \\
\hline Between Groups & 1 & 3.8666 & 3.8666 & 34.020 & $>0.001$ \\
\hline Within Groups & 13 & 1.4775 & 0.1137 & & \\
\hline \multirow[t]{5}{*}{ Total- } & 14 & 5.3441 & & & \\
\hline & & Mean & \multicolumn{3}{|c|}{ Standard Deviation } \\
\hline & 1960-1969 & 7.0169 & \multicolumn{3}{|c|}{0.3570} \\
\hline & $1970-1975$ & 5.9806 & \multicolumn{3}{|c|}{0.3027} \\
\hline & Total 15 & 6.6024 & \multicolumn{3}{|c|}{0.6178} \\
\hline
\end{tabular}


TABLE 4

Analysis of variance between Laurance's two time periods (lagged) and Procurement plus RDTE expenditures (1967\$)

\begin{tabular}{|c|c|c|c|c|c|}
\hline Source & D.F. & Sum of Squares & Mean Squares & \multirow{2}{*}{$\frac{\text { F Ratio }}{7.831}$} & \multirow{2}{*}{$\frac{\text { F Prob. }}{>.010}$} \\
\hline Between Groups & 1 & 99.8141 & 99.8141 & & \\
\hline With in Groups & 13 & 165.6906 & 12.7454 & & \\
\hline \multirow[t]{5}{*}{ Total } & 14 & 265.5047 & & & \\
\hline & & Mean & $\underline{\text { Stan }}$ & ard Deviation & \\
\hline & $1960-1969$ & 24.4216 & & .4624 & \\
\hline & $1970-1975$ & 19.1561 & & .7359 & \\
\hline & Total 15 & 22.3154 & & 3548 & \\
\hline
\end{tabular}

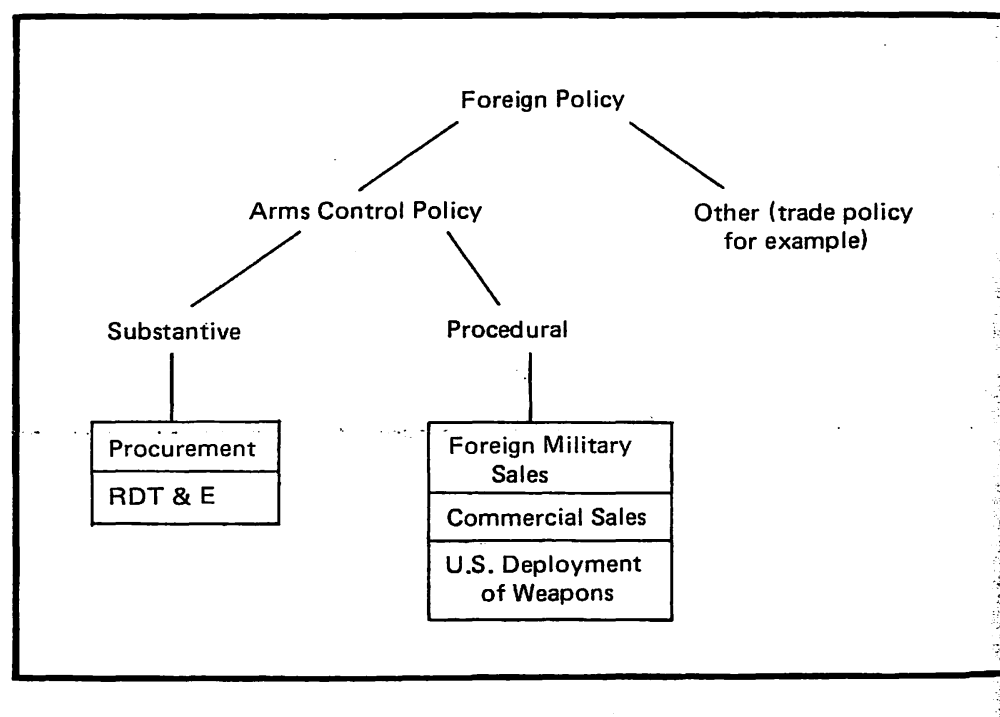

FIGURE 2: Typology of Arms Control Policy.
Arms policy, then, would include the placement of U.S. weapons in the hands of foreign governments, whether by sale or by "gift." The sale of technologically advance weapons systems to Middle Eastern states, for example, may serve to further U.S. policy goals of maintaining stability in the area, increasing Arab dependence upon U.S. as opposed to U.S.S.R. weapons supply and working toward a solution to an unfavorable balance-of-payments problem. Laurance's exclusive focus on defense budgetary outputs as an indication of the Congressional role in the arms control policy will not yield appropriate results if that policy is based upon other means of implementation than DoD purchase. Arms policy must be assessed in terms of all policy measures aimed at the dispersion of weapons systems to both U.S. forces and foreign governments.

\section{CHANGES IN IMPLEMENTATION}

In Arms Controls Today (1976:1), Edward Luck has presented evidence that arms policy is not implemented solely, or even primarily, by DoD purchase.

The pace of U.S. arms transfers has more than doubled over the last ten years, while the principal means of financing has shifted from aid to sales, which now constitutes more than 95 percent of the total. Foreign orders for arms sales through U.S. government and commercial channels, under $\$ 1.5$ billion in FY 70, are expected to exceed $\$ 10$ billion in FY 1976 for the third fiscal year in succession.

Figure 3, demonstrates an escalating trend in arms exports for the 1961-1975 time period. The values plotted represent actual exports as opposed to contracts, for all categories: government to government sales, government to government transfers, and commercial sales.

In fact, it can be demonstrated that just as budget outputs form to statistically different populations, arms exports follow the same pattern. As Table 5 indicates, the mean value of the second period is substantially higher than that of the earlier period-even 


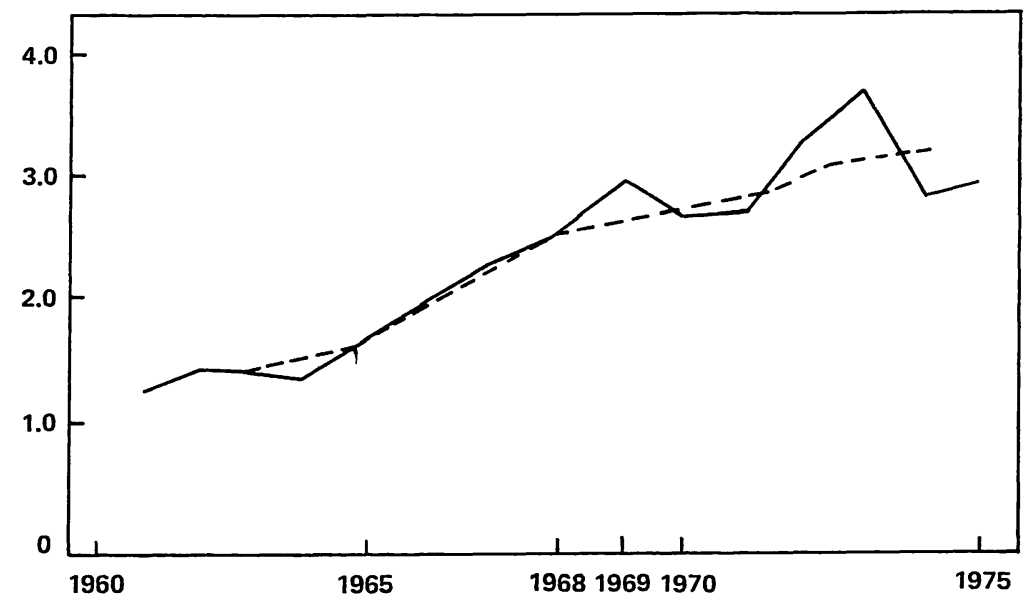

FIGURE 3: Value of U.S. arms exports (in 1967 current dollars), 1961-1975. SOURCE: Broken line indicates a 3-year average trend line.

TABLE 5

Analysis of variance between Laurence's time periods (lagged) and the value of arms exports (1967\$)

\begin{tabular}{|c|c|c|c|c|c|}
\hline Source & D.F. & Sum of Squares & Mean Squares & F Ratio & F Prob. \\
\hline Between Groups & 1 & 7.3658 & 7.3658 & 35.306 & $>0.001$ \\
\hline Within Groups & 13 & 2.7121 & 0.2086 & & \\
\hline \multirow[t]{7}{*}{ Total } & 14 & 10.0779 & & & \\
\hline & & Mean & \multicolumn{3}{|c|}{ Standard Deviation } \\
\hline & $1961-1968$ & 1.6689 & \multicolumn{2}{|c|}{0.5254} & \\
\hline & $1969-1975$ & 3.0735 & \multicolumn{2}{|c|}{0.3606} & \\
\hline & Total 15 & 2.3244 & \multicolumn{2}{|c|}{0.8484} & \\
\hline & \multicolumn{2}{|c|}{ Fixed Effects Model } & \multicolumn{2}{|c|}{0.4568} & \\
\hline & \multicolumn{2}{|c|}{ Random Effects Model } & \multicolumn{2}{|c|}{0.9954} & \\
\hline
\end{tabular}

controlling for inflation (the values were converted to 1967 constant dollars). 5

To recapitulate thus far, Laurance has argued that in response to changes in its external environment the Congress has adopted a conflictual role regarding requests from the executive bureaucracy. However, any implications for arms policy, and hence Melman's thesis, rest heavily on a narrow conception of arms policy. When a broader, but more realistic conceptualization of arms policy defined by Yarmolinsky is applied, it is evident that the period of increased constraint upon defense budgets mirrors a period of increased arms sales.

What has not been demonstrated, of course, is that the two events-decreased DoD expenditures and increased arms transfers through sales-are related. To do so would demand sophisticated techniques for correlating time series data with sufficient controls to insure that both phenomena are not a result of other variables. Indeed, the balance of payments is often cited by U.S. government officials as the reason for increased sales. ${ }^{6}$ The ability to carry out these statistical manipulations is hindered by the complexity of the export data. One must be able to separate the various categories-DoD sales, foreign military sales, military assistance program transfers-to attain the quality of measurement and to meet the assumptions regarding error required by the necessary statistical operations. Since the purpose of this paper was to focus upon the possibility of merit in Melman's thesis, these operations are considered as being outside its scope. The problem can be addressed theoretically, however.

\section{SYSTEMS VS SYMBOLIC POLITICS}

For Laurance's findings to seriously question Melman's thesis, they would have to demonstrate changes in output, rather than changes in process. It appears that his analysis rests too heavily upon systems theory and its assumptions that changes in the political environment produce changes in policy. That is, given increased demands for decreased defense spending, the Congress reacts to these demands by decreasing the defense budget, which in turn implies increased Congressional presence in 
the arms policy making. The linkage between policy and process is assumed. Davis and Dolbeare (1968), Edelman (1964, 1971), and Dolbeare and Edelman $(1971,1977)$ have demonstrated that the assumption of systems is untenable for public policy analysis.

An alternate framework proposed by Edelman locates initial focus on policy outcomes. He argues that conflict over policy is often of a "ritualistic" nature. "Public controversy over an issue functions to help participants in the debate accept an outcome that deviates from their beliefs about the optimum policy" (Edelman, 1971:45). From this perspective, Congressional activity expressing concern over arms policy as reflected by the defense budget may serve to ease the transition to an alternate, less visible means of maintaining current arms policy. If one begins with the notion of political conflict as a means to manipulate public quiescience in circumstances surrounded by ambiguity, one would argue, as does Melman, that arms policy has remained unchanged. The oil crisis, unemployment, and balance-of-payments become justificatory symbols, not reasons, for current arms policy. It should be noted that while Congress had the legal powers to prevent military equipment transfers over $\$ 25$ million since 1974 and government sales over $\$ 7$ million since 1976, such action required a concurrent resolution by both parts of the Congress-an extremely unlikely probability demonstrated by the fact that it has yet to occur. ${ }^{7}$ The increased Congressional activity noted by Laurance and the accompanying cuts in defense budgets point to changes in implementation of policy, not to changes in the policy itself.

The logic for current arms policy appears best set forth by the U.S. Arms Control and Disarmament Agency in its 15th Annual Report (1976:44):

There are also domestic economic benefits derived from U.S. exports of conventional arms. In some cases the increased production for export reduced the unit cost of weapons supplied to U.S. forces, contribute to unemployment of manpower and capital in defense industries, and helps keep critical production lines open. More broadly, arms exports contribute to a favorable U.S. balance of payments position and may help open foreign markets for U.S. civilian exports.
TABLE 6

Value of contracts to Lockheed for military purchases

by foreign governments for 1975

\begin{tabular}{lc}
\hline & $\begin{array}{c}\text { Contract Value (Millions of } \\
\text { U.S. dollars) }\end{array}$ \\
\cline { 2 - 2 } Austrialia & 140.0 \\
Canada & 950.0 \\
Federal Republic of Germany & 317.7 \\
Greece & 120.0 \\
Netherlands & 82.5 \\
Republic of Korea & 2.0 \\
Total & 1612.2 \\
Total U.S. Contracts & 943.0 \\
\hline
\end{tabular}

SOURCE: Wall Street Journal Index, 1975. 
Table 6 lists the economic benefits which accrued to Lockheed in 1975 through current arms policy. It appears, at least in Lockheed's case, that the industrial sector has suffered little adverse effect from changes in arms policy implementation or the "new role of Congress."

\section{CONCLUSION}

The effects of this policy will remain a subject of great debate-as will indeed the likelihood of the existence of a military-industrial complex. For those MIC theorists who have argued that defense policy is at the cost of meeting social needs, the usual procedure of correlating defense expenditures and social expenditures will no longer work. As Laurance correctly observed, defense budgets have declined (as social welfare expenditures have claimed a greater part of the federal budget). For the critics that argue that the MIC operates only within the national security parameters set by the Congress, strong evidence to the contrary is not available. For MIC theorists operating at the level of Melman, however, this critique is irrelevant. If Melman's thesis of a state managed economy is correct, the Congress is as much subject to the defense bureaucracy as the rest of us.

I make no claims to resolving the issue in this paper. Its sole purpose-one that I feel was achieved-was to keep the question open in light of Laurance's findings. I have attempted to demonstrate the examination of the issue, where arms control policy is concerned, requires a conceptualization capable of containing the various manifestations of that policy. I have also attempted to show that the symbolic politics framework is extremely useful for describing changes in those manifestations. At best, then, this paper can be considered as a call for research.

\section{NOTES}

1. It should be noted that Lieberson argues that a number of similar "other-industrial complexes" also exist in other government activities characterized by high annual expenditures (education, for example).
2. Richard Smoke (1975) concluded his examination of the MIC literature with the statement that: "The first rush of military-industrial polemics (fueled substantially by anti-Vietnam War era sentiment) has faded away, and a more thoughtful second generation of literature is appearing, systematically critical still, but soberer and more noteworthy (e.g., Melman, 1974).'

3. Gary L. Wamsley, lectures in Political Science 833, Fall Semester, 1976 Kansas University.

4. These findings are essentially the same as those of Woods (1973) as reported by Laurance. Woods used these budget categories because, based upon previous literature, they were the categories least susceptible to incrementalism in the budgetary process.

5. Note that there is a one year difference in time periods shown in Table 5 from those used by Laurance. This difference is required to make the periods equivalent since the 1969 budget, for example, is made during 1968.

6. Addressing this argument, Melman states: "Officials of the state management seized upon the balance-of-payments problem (which they had been instrumental in creating) as justification for enlarging foreign orders and sales from the aerospace-industry firms (which they direct) in order to keep them occupied, thereby 'maintaining the industrial-base'-their own decision power, that is. Other options for coping with balance-of-payments or military-industry problems were obviously ruled out." (1974:269-270).

7. Survey of Congressional Quarterly Almanacs 1970-1975, and Congressional Quarterly Weekly Reports, 1976.

\section{REFERENCES}

Barnet, R.J.

1969 The Economy of Death. New York: Atheneum.

1971 "The Game of Nations." Harper's Magazine, (November) 1971. 
Mid-American Review of Sociology

Cohen, B.C.

1973 The Public's Impact on Foreign Policy. Boston: Little, Brown.

Congressional Quarterly Almanac

1970 Washington, D.C.: Congressional Quarterly, Inc.

1971 Washington, D.C.: Congressional Quarterly, Inc.

1972 Washington, D.C.: Congressional Quarterly, Inc.

1973 Washington, D.C.: Congressional Quarterly, Inc.

1974 Washington, D.C.: Congressional Quarterly, Inc.

1975 Washington, D.C.: Congressional Quarterly, Inc.

Congressional Quarterly Weekly Reports

1976 Washington, D.C.: Congressional Quarterly, Inc.

Davis, J. and K. Dolbeare

1968 Little Groups of Neighbors: the Selective Service Systems. Chicago: Markham Publishing Co.

Dolbeare, K. and M. Edelman

1971 American Politics: Policies, Power and Change. Lexington, Mass.: D.C. Heath.

1977 American Politics: Policies, Power and Change, 3rd Edition. Lexington, Mass.: D.C. Heath.

Downs, A.

1966 Inside Bureaucracy. Boston: Little, Brown.

Edelman, $M$.

1964 - The Symbolic Uses of Politics: Urbana, Ill.: University of Illinois Press.

1974 Politics as Symbolic Action: Mass Arousal and Quiescence. New York: Academic Press.

Heilbroner, $\mathrm{R}$.

1970 Military America. New York Review of Books. 15:2.
U.S. Arms Control Policy

Horowitz, D. (ed.)

1970 Corporation and the Cold War. New York: Modern Reader.

Kantor, A.

1972 "Congress and the Defense Budget: 1960-1970." American Political Science Review. 66:129-143

Kaufman, R.

1970 The War Profiteers. Indianapolis: Bobbs-Merrill.

Kolko, G.

1970 The Politics of War. New York: Random House.

Laurance, E.

1976 "The Changing Role of Congress in Defense Policy-Making." Journal of Conflict Resolution. 20:213-253.

Lens, $\mathrm{S}$.

1970 The Military-Industrial Complex. Philadelphia: Pilgrim.

Lieberson, S.

1972 “An Empirical Study of Military-Industrial Linkages." In S. Sarkesian (ed.), The Military-Industrial Complex: $A$ Reassessment. Beverly Hills, Calif.: Sage.

Luck, E.

1976 "Does the U.S. Have a Conventional Arms Sales Policy?" Arms Control Today, (May) 1976.

Magdoff, $\mathrm{H}$.

1969 The Age of Imperialism: The Economics of U.S. Foreign Policy. New York: Monthly Review Press.

Melman, S.

1970 Pentagon Capitalism. New York: McGraw-Hill.

1974 The Permanent War Economy: American Capitalism in Decline. New York: Simon and Schuster (Touchstone Editions). 
Mid-American Review of Sociology

1975 "Twelve Propositions on Productivity and War Economy." Armed Forces and Society. 1:490-497.

Perlo, V.

1963 Militarism and Industry. New York: International Publishers.

Russet, B.

1967 "Who Pays For Defense." American Political Science Review. 63:412-426.

Spanier, J. and E. Ulsamer

1974 How American Foreign Policy is Made. New York: Praeger.

Stevenson, P.

1973 "The Military-Industrial Complex: An Examination of the Nature of Corporate Capitalism in America." Journal of Political and Military Sociology. 1:247-259.

Yarmolinsky, A.

1972 "The President, the Congress, and Arms Control." In S. Sarkesian (ed.), The Military-Industrial Complex: A Reassessment. Beverly Hills, Calif.: Sage.

\section{NOTES AND COMMENTS}

Dear Editor:

Please consider the enclosed paper, "On the Relationship between Dummy Variable Regression and Multiple Classification Analysis," for publication in your journal.

A note on its genesis is in order. The paper was written for the benefit of my colleagues at the Center for the Study of American Pluralism who on occasion have used these two methods in the past. The paper was very well received and one of our staff gave me a notice concerning your publication, suggesting that the paper might be of general interest to graduate students in the social sciences. Since the paper was written emphasizing the functional relationship between the two methods, I agreed that this was indeed the best audience for the discussion and example presented.

One of the perennial problems encountered in data analysis, and sample survey data analysis in particular, is estimating predictive models which employ a metric predicted variable and categorical (nonmetric) predictors. The method designed to handle this problem most often discussed in elementary statistics texts is analysis of variance (ANOVA). ANOVA however is actually a generic term for a number of estimation strategies employing categorical predictors. The type of ANOVA discussed in a beginning statistics text is only the simplest of these and is applicable only under very restrictive conditions. The more complex forms of ANOVA are less restrictive in their assumptions, but suffer the drawback of being inferential only. That is, they test statistical significance (the F-test) and estimate the variance explained in the predicted variable, but do not estimate the pattern or size of the effects of the predictors. Since pattern and size of effect are just as important as statistical significance, ANOVA alone often falls short of a researcher's goals.

Two methods of solving this last problem of estimating the effects of categorical predictors, as well as their statistical significance, are dummy variable regression (DVR) and multiple classification analysis (MCA). The former is a special case of 